\title{
CONTROLLING OF POTENTIAL HAZARD IN POTATO CHIPS PROCESSING THROUGH FOOD SAFETY MANAGEMENT SYSTEM FSMS (ISO 22000)
}

\author{
Rasha A. M. Eissa ${ }^{(1)}$, M. A. Salem ${ }^{(1)}$ and S. Y. Elsanat(2) \\ (1) Food Science and Technology Department, Faculty of Agriculture, Tanta University, \\ Egypt \\ (2) Food Science and Technology Department, Faculty of Agriculture, Kafrelshiekh \\ University, Egypt
}

Received: Oct. 21, 2019

Accepted: Nov. 12, 2019

ABSTRACT: The purpose of this study is to design Hazard Analysis and Critical Control Point (HACCP) plan for potato chips production through food safety management system F.S.M.S ISO 22000 based on actual conditions in the plant. A specific model has been developed to boost the safety and quality of potato chips product in this plant. The prerequisite programs (PRPS), operational prerequisite programs (OPRPs), hazards, critical control point (CCP), preventive measure, critical limits, monitoring procedure and corrective actions have been designed in this HACCP plan. Microbiological analysis for incoming flavors were within the acceptable limits and thus the incoming shipments were accepted and no acceptance from the supplier in case of out of the acceptable limits. The results showed that microbiological examination of raw potatoes before and after frying that frying process could significantly reduce all microorganisms in raw potatoes to the acceptable level on two processing lines. $A$ program of cleaning and disinfection of production lines and a personal hygiene program for the workers and ensuring the effectiveness of them as well as the quality of the water entering the manufacturing process. Chemical, microbiological, physical and sensory tests were conducted to ensure the safety and quality of the finished product.

Key word: Potato chips plant, ISO 22000, HACCP, Hazard, Critical limit.

\section{INTRODUCTION}

Recently, consumers have focused on food safety, which does not contribute to disease, microbial infection or poisoning. Food safety has become an important and essential criterion for consumers to choose food regardless of its importance and nutritional value. A food safety-risk analysis: is essential not only to produce or manufacture high quality products to ensure safety and protect public health, but also to comply with international and national standards and market regulations. There are three types of food hazards: natural, biological and chemical in addition to allergens and radiological substance (Codex, 2009; Noble et al., 2009; Easdani et al., 2012 and ISO22000, 2018).
The ISO 22000 international standard specifies the requirements for a food safety management system that involves interactive communication, syste $\mathrm{m}$ management, prerequisite programs (PRPs), hazard analysis and critical control point (HACCP) principles (ISO 22000, 2018).

Potato chips is a food product prepared from potato tubers after cleaning, peeling, slicing and frying in suitable edible food oil (Zhang and Peterson, 2018). Potato chips are the most popular snack food in Egypt and are devoured at a rate of 100 million pounds annually. Potato chips are a predominant part of the snack food. According to the snack food association potato chips constitute $40 \%$ of snack 
food consumption, beating out pretzels and popcorn in spite of the fact that hardly anyone thinks potato chips are nutritious and convenience food market (Majcher and Jelen, 2005; Abd-Elhak, 2005 and Dogan and Kokini, 2007).

The objective of this study is to ensure that all products manufactured by the company were safed and fit for consumption "our end customer expects that "so food safety as one of the highest priorities in doing business because it saves the business money in the long run, avoids you poisoning your customers and testing improves staff motivation and efficiency. In addition, design HACCP plan for potato chips production based on actual conditions in the plant to produce safe product.

\section{MATERIALS AND METHODS}

\section{Materials:}

The present study was carried out at processing and packaging Herms potato chips provided from a plant at Central Delta, Egypt, during the spring season of the year 2018. All chemicals, solvents, media in this study, were purchased from El-Gomhorea Company for chemicals and drugs, Tanta, Egypt.

\section{Methods:}

\subsection{Chemical analysis of potato chips.}

Moisture and oil were determined by NDS infrared engineering a device used to measure the moisture and oil ratio of the chips product in less than 10 seconds. The Micro-Kjeldahl method was used to determine the total nitrogen and thereafter its value was multiplied by the factor of 6.25 to get the crude protein content. Ash content was determined by ashing the samples in an electric muffle at $550^{\circ} \mathrm{C}$ until constant weight was maintained. $\mathrm{NaCl}$ was determining by Mettler DL22 by titration via AgNo3. The amounts of total carbohydrates were determined by difference. The total energy was calculated using the Atwater factors; whereas $1.0 \mathrm{~g}$ of each carbohydrate and protein provide 4.0 $\mathrm{Kcal}$, and1.0g of fat provide $9.0 \mathrm{Kcal}$, as reported by (A.O.A.C., 2005). Free fatty acids (FFA) was determined according the method described by (A.O.C.S., 2005), by titration ethanolic oil extract with $\mathrm{NaOH}(0.1 \mathrm{~N})$ until appearance of the light pink color. Peroxide value was determined according to the method described by A.O.A.C. (2005), and the results were calculated as mill equivalent of oxygen absorbed by kilogram oil (meqO2 kg-1 oil).

\subsection{Prerequisite programs (PRPs): \\ 2.2.1. Factory zoning layout requirements.}

This zoning plan is a mandatory part of a factory master plan. Based on the requirements of each area, the plant is divided into three zones high, medium, basic hygiene zone. Pathogen monitoring programs will be established in high hygiene zone. A full description of two potato chips (processing \& packaging) lines starting from raw materials receiving, storage...etc. The flow diagram was constructed by HACCP team as shown in Figure (1).

\subsubsection{Incoming raw materials.}

Potato and flavors were examined. Samples were drawn by trained personnel for microbiological tests to ensure their safety based on specific criteria.

\subsubsection{Cleaning and sanitation programs requirements}

Material safety data sheets (MSDS) were maintained and available for all cleaning and sanitizing chemicals were clearly labeled and stored in secured areas with limited access. Cleaning process has done in place (CIP) every 2 
weeks and cleaning out place (COP) was include all equipment and product contact surfaces.

\subsubsection{Personal hygiene policy}

Personal swabs were taken before and after cleaning hands to ensure that staff complies with person hygiene policy. Others programs, as appropriate and they are managed in PRPs list as shown in Table (1).

\subsection{Sensory evaluation of finished product. \\ Potato finished products were sensory tested for their color, odor, texture (crispness), taste and overall acceptability on a 1 to 10 hedonic scale as described by El-Sheikh et al. (1999).}

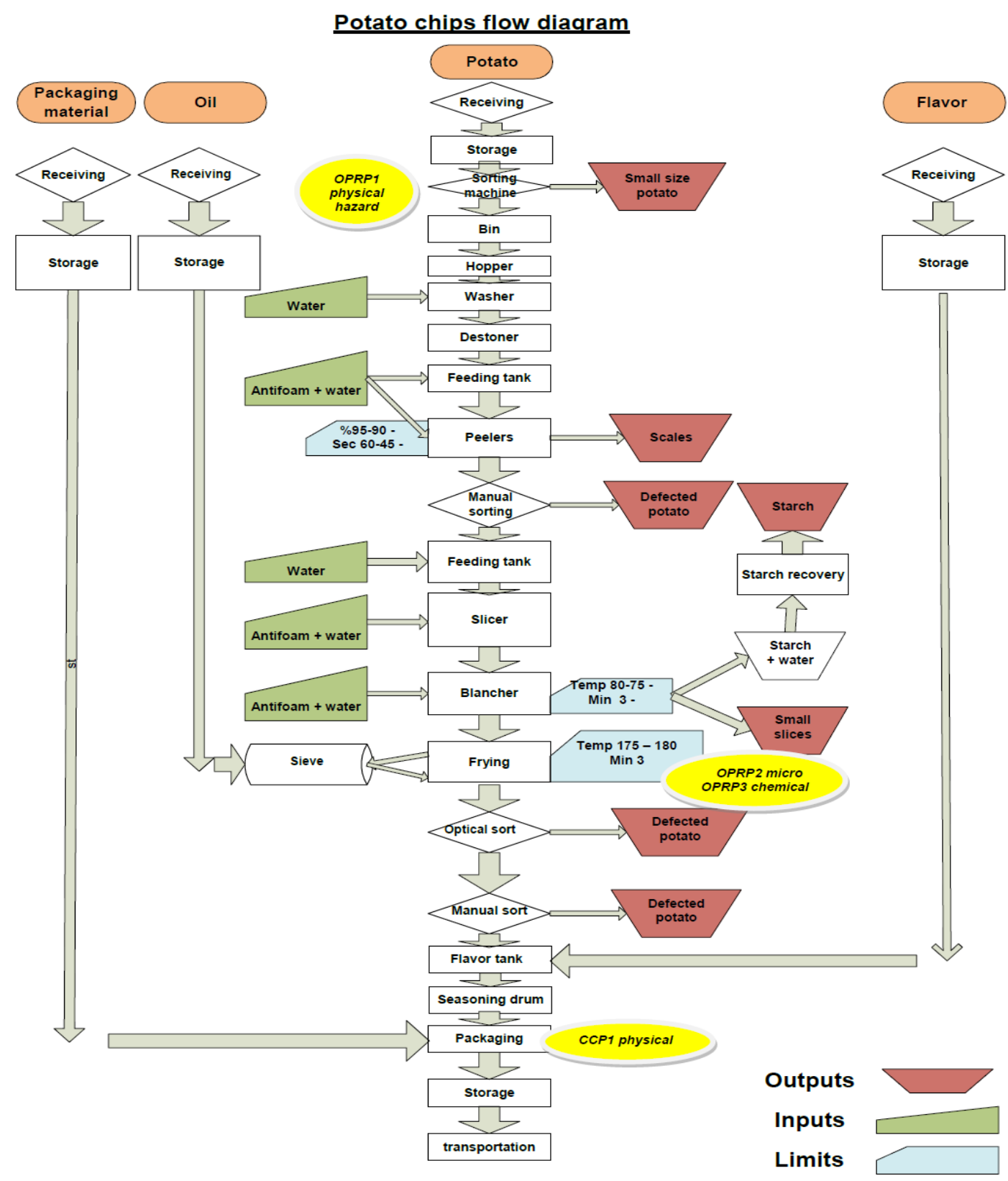

Fig. (1): Flow diagram a full description of two potato chips (processing \& packaging) lines. 
Rasha A. M. Eissa, et al.,

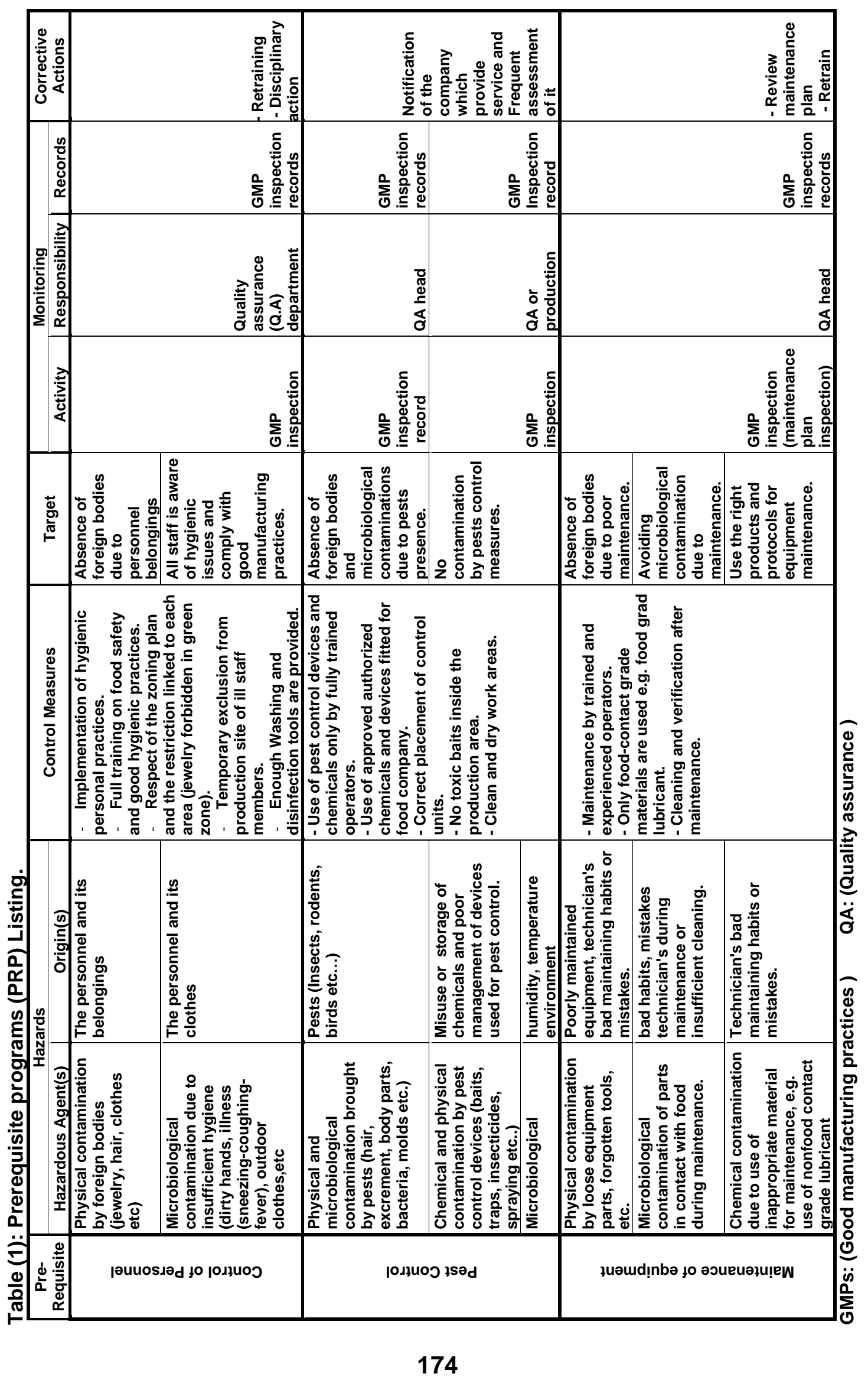




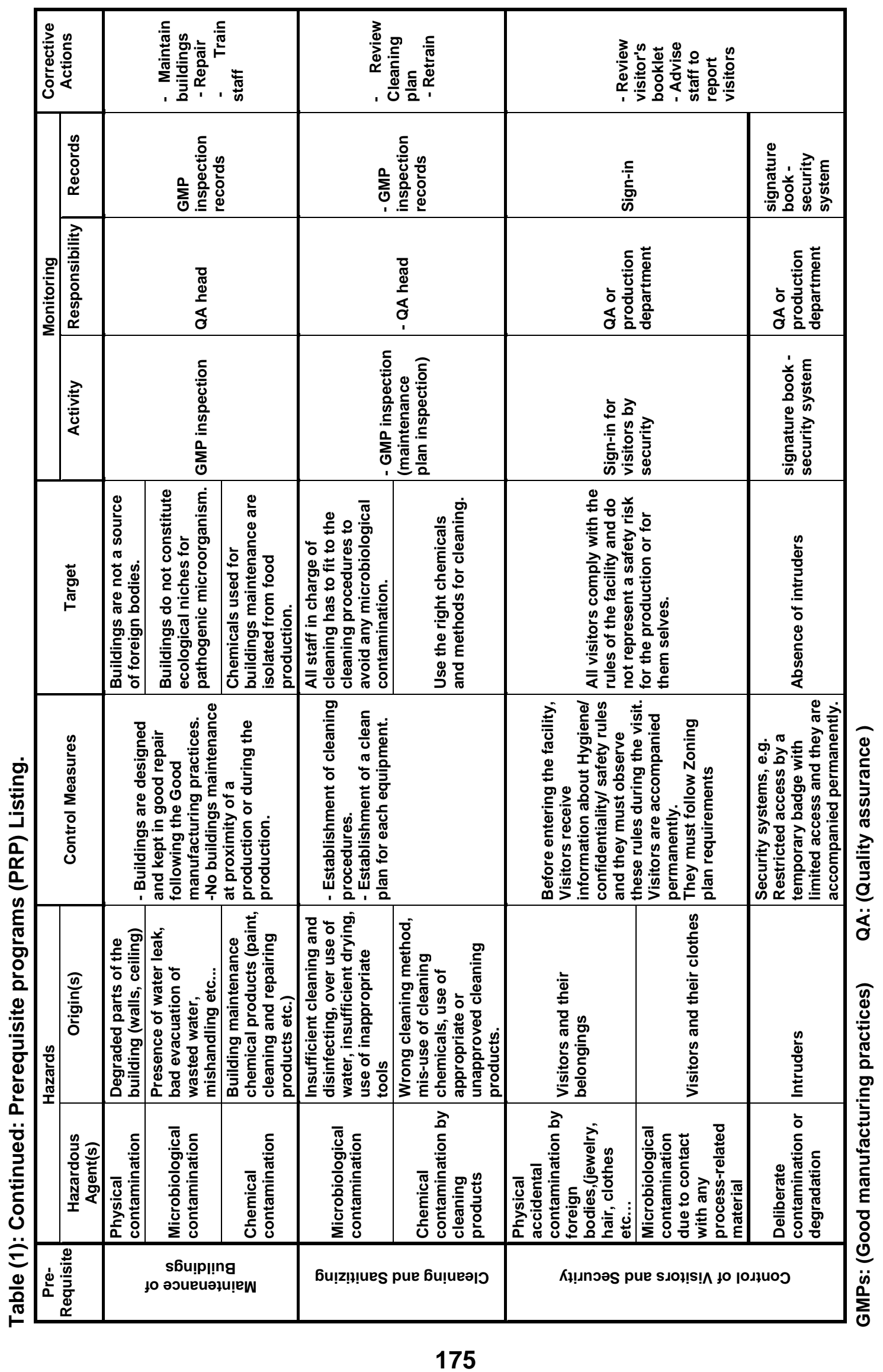


Rasha A. M. Eissa, et al.,

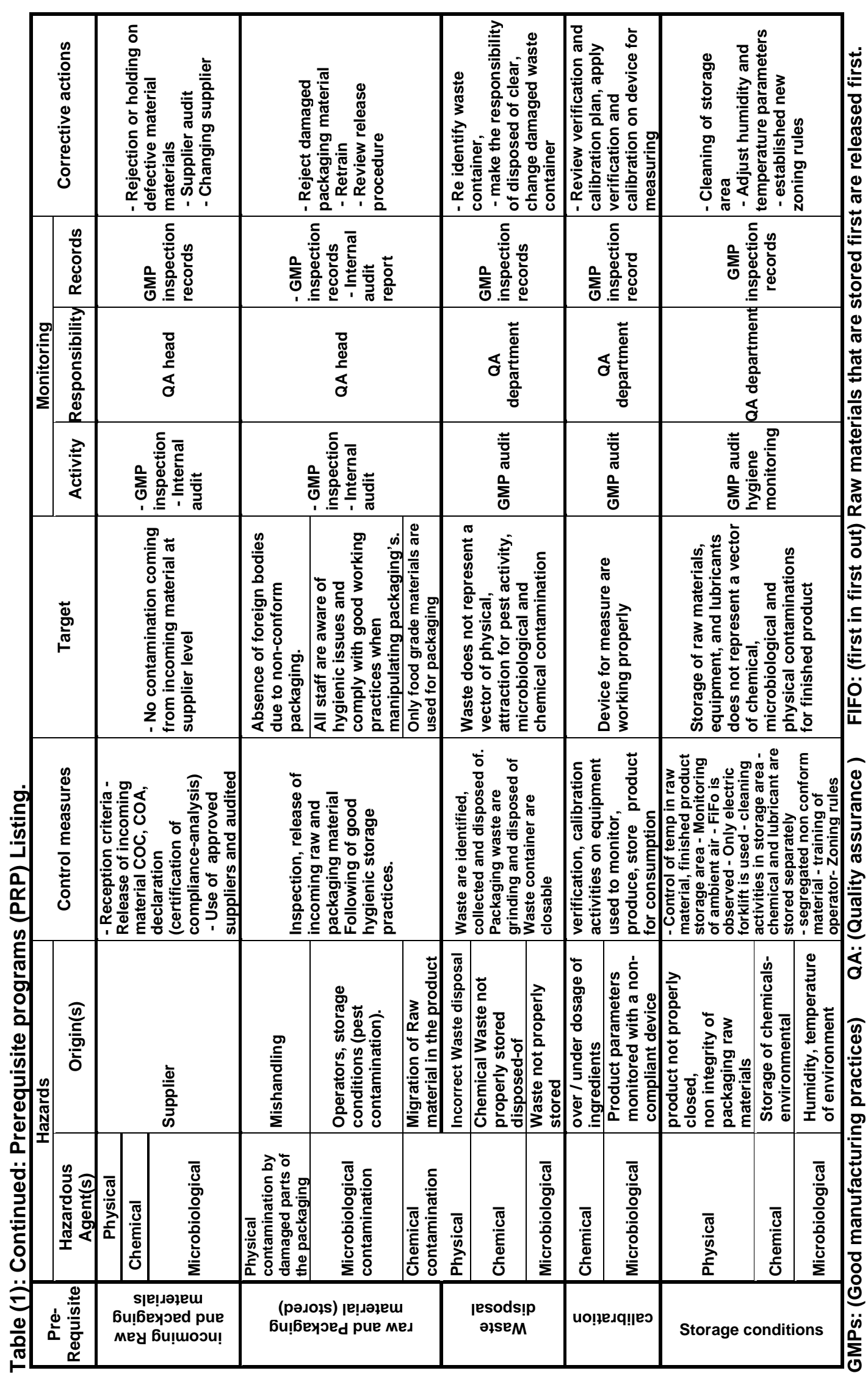




\section{RESULTS AND DISCUSSIONS}

\section{Prerequisite programs (PRPs):}

Steps or procedures that control the operational conditions within the food establishment, allowing for environmental conditions that are favorable for safe and wholesome food manufacturing. Systems that are normally in place before the HACCP plan is developed to ensure the business is operating according to Codex general principles of food hygiene, relevant codes of practice and relevant food safety legislation (ISO 22004, 2014).

\subsection{Factory zoning (Layout).}

The air in the high hygiene area was filtered and monitored by air sampling which as one of the applied microbiological programs to measure the air conditions efficiency. Air sampling test was used to evaluate the microbiological load of the high hygiene area air surrounding different locations of packaging line (seasoning area). The obtained results are shown in Table (2).
Results revealed that the air after implementing hygienic requirements of seasoning area by filtrated air was free from any pathogenic bacteria and has low microbial load of bacteria and mold \& yeast counts but the air of the same area before implementing hygienic requirements were having high loads of bacteria, mold and yeast counts. In in in Case of devition, corrective action must be taken by checking air filter, maintain or change filter if necessary and the retest again is required. Our results were in agreement with (Khateb Heba, 2014).

\subsection{Incoming flavors}

Conducting microbiological analysis on the incoming flavors to ensure their food safety and compliance with the specifications. The samples were withdrawal according to ISO 5928. From the results shown in Table (3), we can find that samples flavors were within the limits and thus incoming shipments were accepted. In case of deviation from the limits, it is holded, rejected and returned back to the supplier.

Table (2): Microbiological analysis of high hygiene zone before and after implement hygienic requirements (air sampling).

\begin{tabular}{|c|c|c|c|c|c|c|}
\hline \multirow{2}{*}{$\begin{array}{l}\text { Seasoning } \\
\text { area }\end{array}$} & \multirow{2}{*}{$\begin{array}{l}\text { Test } \\
\text { time }\end{array}$} & \multicolumn{5}{|c|}{ Microbial count (cfu/plate) } \\
\hline & & $\begin{array}{l}\text { Total plate } \\
\text { count }\end{array}$ & $\begin{array}{l}\text { Mold } \\
\text { \&yeast }\end{array}$ & $\begin{array}{c}\text { Staphylococcus } \\
\text { aureus }\end{array}$ & E. coli & $\begin{array}{l}\text { Bacillus } \\
\text { cereus }\end{array}$ \\
\hline Limit & ---- & $<50$ & $<30$ & Nil & Nil & Nil \\
\hline \multirow{2}{*}{ Front } & Before & $200^{\mathrm{a}}$ & $100^{\mathrm{a}}$ & Nil & Nil & Nil \\
\hline & After & $33^{\text {de }}$ & $20^{d}$ & Nil & Nil & Nil \\
\hline \multirow{2}{*}{ Middle } & Before & $150^{b}$ & $70^{\mathrm{b}}$ & Nil & Nil & Nil \\
\hline & After & $20^{\mathrm{e}}$ & $20^{d}$ & Nil & Nil & Nil \\
\hline \multirow{2}{*}{ End } & Before & $75^{c}$ & $45^{c}$ & Nil & Nil & Nil \\
\hline & After & $15^{e}$ & $15^{d}$ & Nil & Nil & Nil \\
\hline
\end{tabular}

*cfu/plate = colony forming unit/plate.

*The limits are according to internal specifications.

* Values followed by different letter in columns are significantly different at $p<0.05$. 
Rasha A. M. Eissa, et al.,

Table (3): Microbiological analysis of cheese, kebab and ketchup flavors samples.

\begin{tabular}{|l|c|c|c|c|}
\hline \multirow{2}{*}{$\begin{array}{c}\text { Microbiological tests } \\
\text { (cfu/gm) }\end{array}$} & \multirow{2}{*}{ limits } & \multicolumn{3}{|c|}{ Flavors } \\
\cline { 3 - 5 } & & Cheese & Kebab & Ketchup \\
\hline Total plate count & $\leq 100000$ & $5.3 \times 10^{2 \mathrm{c}}$ & $7.3 \times 10^{2 \mathrm{~b}}$ & $8.6 \times 10^{2 \mathrm{a}}$ \\
\hline mold\& yeast & $\leq 1000$ & $1.2 \times 10^{2 \mathrm{c}}$ & $1.4 \times 10^{2 \mathrm{~b}}$ & $1.5 \times 10^{2 \mathrm{a}}$ \\
\hline Bacillus cereus & $\leq 1000$ & $\mathrm{Nil}$ & $\mathrm{Nil}$ & $\mathrm{Nil}$ \\
\hline Salmonella & $\mathrm{Nil}$ & $\mathrm{Nil}$ & $\mathrm{Nil}$ & $\mathrm{Nil}$ \\
\hline Staphylococcus aureus & $\mathrm{Nil}$ & $\mathrm{Nil}$ & $\mathrm{Nil}$ & $\mathrm{Nil}$ \\
\hline E. coli & $\mathrm{Nil}$ & $\mathrm{Nil}$ & $\mathrm{Nil}$ & $\mathrm{Nil}$ \\
\hline Coliform group & $\leq 10$ & $\mathrm{Nil}$ & $\mathrm{Nil}$ & $\mathrm{Nil}$ \\
\hline
\end{tabular}

*cfu/gm = colony forming unite $/ \mathrm{gm}$ and Salmonella only $/ 25 \mathrm{gm}$ :

*The limits are according to internal specifications as per agreement with supplier.

* Values followed by different letter in rows are significantly different at $p<0.05$.

\subsection{Cleaning and sanitation program.}

For all cleaning operations, a visual inspection was performed after cleaning. The effectiveness of cleaning was monitored and results documented. Table (4) shows the results of the microbiological tests of the swabs were taken from different equipment from the processing and packaging lines before and after the implementation of the cleaning and sanitation programs (C\&S). The significant decrease in total plate count can be observed clearly, with no pathogens microorganisms (Staphylococcus aureus, Bacillus cereus, Enterobacteriaceae) and all microorganisms have been reduced to safe level after implementing (C\&S) programs. In case of deviation and the results out of the limits corrective action should be taken by re-clean, re-use of sanitizer (devosan) again, training, awareness of employees and reswabbing and retest again. The production will not start working unless the results within the acceptable limits.

Our results in agreement with (Forsythe and Hayes, 1998 and Khatab
Heba, 2014) who reported that standard number of good microbial load of spoilage microorganisms of food contact surfaces ranged between $2-10 / \mathrm{cm}^{2}$ while the safe microbial load number is less than $1 / \mathrm{cm}^{2}$. It was clear also that there was no control in this place already before implementing C\&S programs. We had poor cleaning system in food contact equipment and control has not been effective so that is why it was important that corrective action was taken to insure safety food product.

\subsection{Personal hygiene.}

Table (5) presents the microbiological analysis results of swabs were taken before and after implement workers hygiene CSPs from two processing line (sorting area after frying) and two packaging line (additive flavoring area) to evaluate personal hygiene and ensure the effectiveness cleaning and disinfection program for workers. The results were indicated high contamination with total plate count with the presence of pathogenic microbes (Staphylococcus aureus, Enterobacteriaceae) before cleaning \& disinfecting of hands. 
Controlling of potential hazard in potato chips processing through food safety....

Table (4): Microbiological analysis of swabs taken from Equipment of two processing and packaging lines before and after implementation of C\&S programs.

\begin{tabular}{|c|c|c|c|c|}
\hline Location & Tests \& limits & Line & Before C\&S & After C\&S \\
\hline \multirow{10}{*}{$\begin{array}{l}\text { Bucket } \\
\text { (A) }\end{array}$} & \multirow{2}{*}{ Total plate count (1000 cfu/swab)* } & 1 & $2.2 \times 10^{5 a}$ & $4.7 \times 10^{2 b}$ \\
\hline & & 2 & $9.1 \times 10^{3 a}$ & $4.3 \times 10^{2 b}$ \\
\hline & \multirow{2}{*}{ Mold \& yeast (Nil/swab) } & 1 & $2.1 \times 10^{3 a}$ & Nil \\
\hline & & 2 & $4 \times 10^{2 a}$ & Nil \\
\hline & \multirow{2}{*}{ Staphylococcus aureus (Nil/swab) } & 1 & Detected & Nil \\
\hline & & 2 & Nil & Nil \\
\hline & \multirow{2}{*}{ Bacillus cereus (Nil/swab) } & 1 & Detected & $\mathrm{Nil}$ \\
\hline & & 2 & Nil & Nil \\
\hline & \multirow{2}{*}{ Enterobacteriaceae (Nil/swab) } & 1 & Detected & Nil \\
\hline & & 2 & Nil & Nil \\
\hline \multirow{10}{*}{ Drums ${ }^{(B)}$} & \multirow{2}{*}{ Total plate count (1000cfu/swab) } & 1 & $6.6 \times 10^{5 a}$ & $3.5 \times 10^{2 b}$ \\
\hline & & 2 & $7.8 \times 10^{3 a}$ & $3.8 \times 10^{2 b}$ \\
\hline & \multirow{2}{*}{ Mold \& yeast (Nil/ swab) } & 1 & $1.9 \times 10^{4 a}$ & Nil \\
\hline & & 2 & $2.1 \times 10^{3 a}$ & $\mathrm{Nil}$ \\
\hline & \multirow{2}{*}{ Staphylococcus aureus (Nil/swab) } & 1 & Detected & $\mathrm{Nil}$ \\
\hline & & 2 & Detected & Nil \\
\hline & \multirow{2}{*}{ Bacillus cereus (Nil/swab) } & 1 & Detected & Nil \\
\hline & & 2 & Detected & Nil \\
\hline & \multirow{2}{*}{ Enterobacteriaceae (Nil/swab) } & 1 & Nil & $\mathrm{Nil}$ \\
\hline & & 2 & Detected & Nil \\
\hline \multirow{10}{*}{$\begin{array}{l}\text { Vibrators } \\
\text { (C) }\end{array}$} & \multirow{2}{*}{ Total plate count (1000cfu/swab) } & 1 & $1.2 \times 10^{4 a}$ & $2.9 \times 10^{2 b}$ \\
\hline & & 2 & $3.1 \times 10^{4 a}$ & $5.3 \times 10^{2 b}$ \\
\hline & \multirow{2}{*}{ Mold \& yeast (Nil/swab) } & 1 & $8.1 \times 10^{2 a}$ & Nil \\
\hline & & 2 & $3.6 \times 10^{3 a}$ & Nil \\
\hline & \multirow{2}{*}{ Staphylococcus aureus (Nil/swab) } & 1 & Detected & Nil \\
\hline & & 2 & Nil & Nil \\
\hline & \multirow{2}{*}{ Bacillus cereus (Nil/swab) } & 1 & Detected & $\mathrm{Nil}$ \\
\hline & & 2 & Detected & Nil \\
\hline & \multirow{2}{*}{ Enterobacteriaceae (Nil/swab) } & 1 & Detected & Nil \\
\hline & & 2 & Detected & Nil \\
\hline \multirow{10}{*}{ Ishida(D) } & \multirow{2}{*}{ Total plate count (1000cfu/swab) } & 1 & $9.3 \times 10^{4 a}$ & $2.5 \times 10^{2 b}$ \\
\hline & & 2 & $8.9 \times 10^{5 a}$ & $3.3 \times 10^{2 b}$ \\
\hline & \multirow{2}{*}{ Mold \& yeast (Nil/swab) } & 1 & $2,1 \times 10^{3 a}$ & Nil \\
\hline & & 2 & $1.2 \times 10^{3 a}$ & Nil \\
\hline & \multirow{2}{*}{ Staphylococcus aureus (Nil/swab) } & 1 & Detected & Nil \\
\hline & & 2 & Detected & Nil \\
\hline & \multirow{2}{*}{ Bacillus cereus (Nil/swab) } & 1 & Detected & Nil \\
\hline & & 2 & Nil & Nil \\
\hline & \multirow{2}{*}{ Enterobacteriaceae (Nil/swab) } & 1 & Detected & $\mathrm{Nil}$ \\
\hline & & 2 & Detected & Nil \\
\hline
\end{tabular}

*The limits are according to American public health association. cfu/swab = colony forming unite $/$ swab. $1000 \mathrm{cfu} / \mathrm{swab}=1 \mathrm{cfu} / 100 \mathrm{Cm}^{2}$

* Values followed by different letter in rows are significantly different at $p<0.05$.

*A, B, C, D comparison of means by location. 
Rasha A. M. Eissa, et al.,

Table (5): Microbiological analysis of swabs taken from workers for two processing line (sorting area after frying) and two packaging(flavoring area) lines before and after washing and disinfecting the hands.

\begin{tabular}{|c|c|c|c|c|c|c|c|}
\hline Location & Worker & $\begin{array}{c}\text { Tests } \\
\& \\
\text { Limits }\end{array}$ & $\begin{array}{c}\text { Total } \\
\text { plate } \\
\text { count } \\
1000 \mathrm{cfu} / \\
\text { swab* }\end{array}$ & $\begin{array}{c}\text { Mold } \\
\& \\
\text { yeast } \\
\text { Nil / } \\
\text { swab }\end{array}$ & $\begin{array}{c}\text { Bacillus } \\
\text { cereus } \\
\text { Nil / swab }\end{array}$ & $\begin{array}{c}\text { Staphyloco } \\
\text { ccus } \\
\text { aureus } \\
\text { Nil / swab }\end{array}$ & $\begin{array}{c}\text { Enterobacteria } \\
\text { ceae } \\
\text { Nil / swab }\end{array}$ \\
\hline \multirow{12}{*}{ 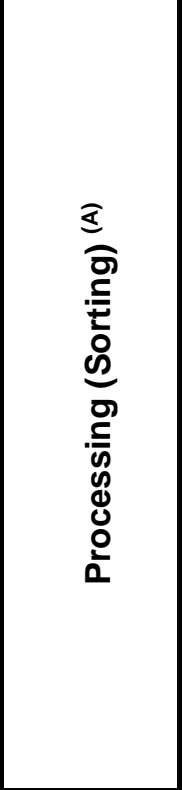 } & \multirow{2}{*}{1} & Before & $3 \times 10^{3 i}$ & $50 \times 10^{2 a}$ & Detected $^{a}$ & Detected $^{\mathrm{a}}$ & $\mathrm{Nil}^{\mathrm{b}}$ \\
\hline & & After & $9 \times 10^{\circ}$ & $\mathrm{Nil}^{\prime}$ & $\mathrm{Nil}^{\mathrm{b}}$ & $\mathrm{Nil}^{\mathrm{b}}$ & $\mathrm{Nil}^{\mathrm{b}}$ \\
\hline & \multirow{2}{*}{2} & Before & $9.6 \times 10^{3 \mathrm{e}}$ & $64 \times 10^{h}$ & $\mathrm{Nil}^{\mathrm{b}}$ & Detected $^{a}$ & Detected $^{a}$ \\
\hline & & After & $4 \times 10^{\circ}$ & $\mathrm{Nil}^{\prime}$ & $\mathrm{Nil}^{\mathrm{b}}$ & $\mathrm{Nil}^{\mathrm{b}}$ & $\mathrm{Nil}^{\mathrm{b}}$ \\
\hline & \multirow{2}{*}{3} & Before & $2.8 \times 10^{3 k}$ & $72 \times 10^{g}$ & $\mathrm{Nil}^{\mathrm{b}}$ & Detected $^{\mathrm{a}}$ & $\mathrm{Nil}^{\mathbf{b}}$ \\
\hline & & After & $5 \times 10^{\circ}$ & $\mathrm{Nil}^{\prime}$ & $\mathrm{Nil}^{\mathbf{b}}$ & $\mathrm{Nil}^{\mathbf{b}}$ & $\mathrm{Nil}^{\mathbf{b}}$ \\
\hline & \multirow{2}{*}{4} & Before & $9.1 \times 10^{3 f}$ & $50 \times 10^{i}$ & Detected $^{a}$ & $\mathrm{Nil}^{\mathrm{b}}$ & Detected $^{\mathrm{a}}$ \\
\hline & & After & $4 \times 10^{\circ}$ & $\mathrm{Nil}^{\prime}$ & Nil & $\mathrm{Nil}^{\mathrm{b}}$ & $\mathrm{Nil}^{\mathrm{b}}$ \\
\hline & \multirow{2}{*}{5} & Before & $4.2 \times 10^{4 a}$ & $87 \times 10^{f}$ & Detected $^{a}$ & Detected $^{\mathrm{a}}$ & $\mathrm{Nil}^{\mathrm{b}}$ \\
\hline & & After & $3 \times 10^{\circ}$ & $\mathrm{Nil}^{\prime}$ & $\mathrm{Nil}^{\mathrm{b}}$ & $\mathrm{Nil}^{\mathrm{b}}$ & $\mathrm{Nil}^{\mathrm{b}}$ \\
\hline & \multirow{2}{*}{6} & Before & $6.2 \times 10^{4 b}$ & $90 \times 10^{f}$ & $\mathrm{Nil}^{\mathrm{b}}$ & Detected $^{a}$ & Detected $^{\mathrm{a}}$ \\
\hline & & After & $7 \times 10^{\circ}$ & $\mathrm{Nil}^{\prime}$ & $\mathrm{Nil}^{\mathrm{b}}$ & $\mathrm{Nil}^{\mathrm{b}}$ & $\mathrm{Nil}^{\mathbf{b}}$ \\
\hline \multirow{12}{*}{ 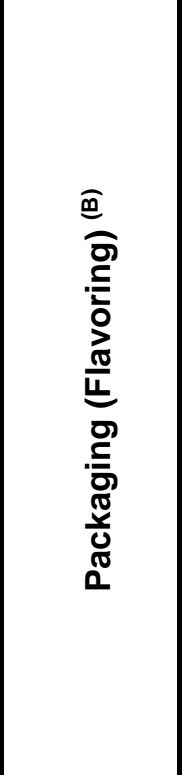 } & \multirow{2}{*}{1} & Before & $2.9 \times 10^{3 j}$ & $4 \times 10^{2 b}$ & Detected $^{\mathrm{a}}$ & Detected $^{a}$ & Detected $^{\mathrm{a}}$ \\
\hline & & After & $7 \times 10^{\circ}$ & $\mathrm{Nil}^{\mathrm{l}}$ & $\mathrm{Nil}^{\mathrm{b}}$ & $\mathrm{Nil}^{\mathrm{b}}$ & $\mathrm{Nil}^{\mathrm{b}}$ \\
\hline & \multirow{2}{*}{2} & Before & $4.8 \times 10^{3 h}$ & $2.5 \times 10^{2 d}$ & Detected $^{a}$ & Detected $^{\mathrm{a}}$ & Detected $^{\mathrm{a}}$ \\
\hline & & After & $1.2 \times 10^{20}$ & $\mathrm{Nil}^{\prime}$ & $\mathrm{Nil}^{\mathbf{b}}$ & Nil & $\mathrm{Nil}^{\mathrm{b}}$ \\
\hline & \multirow{2}{*}{3} & Before & $8.5 \times 10^{3 \mathrm{~g}}$ & $8 \times 10^{k}$ & Detected $^{\mathrm{a}}$ & Detected $^{a}$ & Detected $^{a}$ \\
\hline & & After & $2 \times 10^{2 m}$ & $\mathrm{Nil}^{\prime}$ & $\mathrm{Nil}^{\mathbf{b}}$ & $\mathrm{Nil}^{b}$ & $\mathrm{Nil}^{\mathbf{b}}$ \\
\hline & \multirow{2}{*}{4} & Before & $1.7 \times 10^{4 d}$ & $22 \times 10^{j}$ & Detected $^{\mathrm{a}}$ & $\mathrm{Nil}^{\mathrm{b}}$ & Detected $^{\mathrm{a}}$ \\
\hline & & After & $3 \times 10^{21}$ & $\mathrm{Nil}^{\mathrm{l}}$ & $\mathrm{Nil}^{\mathbf{b}}$ & $\mathrm{Nil}^{\mathbf{b}}$ & $\mathrm{Nil}^{\mathbf{b}}$ \\
\hline & \multirow{2}{*}{5} & Before & $3.2 \times 10^{4 c}$ & $99 \times 10^{e}$ & $\mathrm{Nil}^{\mathbf{b}}$ & Detected $^{\mathrm{a}}$ & $\mathrm{Nil}^{\mathrm{b}}$ \\
\hline & & After & $2.9 \times 10^{3 j}$ & $5 \times 10^{k}$ & Detected $^{a}$ & $\mathrm{Nil}^{\mathrm{b}}$ & $\mathrm{Nil}^{\mathrm{b}}$ \\
\hline & \multirow{2}{*}{6} & Before & $1.4 \times 10^{2 n}$ & $3.2 \times 10^{2 c}$ & Detected $^{a}$ & Detected $^{\mathrm{a}}$ & Detected $^{\mathrm{a}}$ \\
\hline & & After & $6 \times 10^{\circ}$ & $\mathrm{Nil}^{\mathrm{l}}$ & $\mathrm{Nil}^{\mathrm{b}}$ & $\mathrm{Nil}^{\mathrm{b}}$ & $\mathrm{Nil}^{\mathrm{b}}$ \\
\hline
\end{tabular}

${ }^{*}$ The limits are according to American public health association: 1000/swab for total plate count $\mathrm{Nil} / \mathrm{swab}$ for Mold \& yeast Bacillus cereus, Staphylococcus aureus and Enterobacteriaceae.

${ }^{*} \mathrm{cfu} / \mathrm{swab}=$ colony forming unite $/ \mathrm{swab} .1000 \mathrm{cfu} / \mathrm{swab}=1 \mathrm{cfu} / 100 \mathrm{Cm}^{2}$.

* Values followed by different letter in columns are significantly different at $p<0.05$.

${ }^{*} A, B$ comparison of means by location. 
But after implementing effective hand washing program we found all results of swabs taken within the acceptable limit and high contamination was reduced to the acceptable level for all workers awareness, (Easdani et al., 2012).

\section{Efficiency of potato frying}

Many types of spoilage and pathogenic microorganisms exist on fresh, minimally processed, and fully processed potato products. The microbiological quality of finished potato products is influenced by the natural micro flora, processing, handling, and human contact. The natural micro flora of potatoes is influenced by soil and airborne inoculate, agricultural practices, harvesting methods, and storage conditions (Dona and Davidson, 2000).
Frying temperature was set in the range of $175-180^{\circ} \mathrm{C}$ and time of fryer is $3 \mathrm{~min}$. in which was efficient and effective for moisture reduction and microorganism destruction. Table (6) shows the data of practical experiment of two potatoprocessing lines to determine the efficiency of the frying process. The results indicated a high microbial load of raw potato slices before frying in two processing lines. Results showed very high contamination by (Total plate count, Mold \& yeast count, Staphylococcus aureus, Bacillus cereus, E. Coli). After frying the results indicated that frying process could significantly reduce all microorganisms in raw potatoes to the acceptable level on two processing lines according to (E.S: 1629:2017).

Table (6): Microbiological analysis of potato slices before and after frying for two processing lines.

\begin{tabular}{|c|c|c|c|c|}
\hline $\begin{array}{l}\text { Microbiological tests } \\
\text { (cfu/gm) }\end{array}$ & $\begin{array}{l}\text { processing } \\
\text { line }\end{array}$ & $\begin{array}{l}\text { Result before } \\
\text { frying }\end{array}$ & $\begin{array}{l}\text { Result after } \\
\text { frying }\end{array}$ & Specification \\
\hline \multirow{2}{*}{ Total plate count } & 1 & $3.6 \times 10^{6 a}$ & $10 \times 10^{b}$ & \multirow{2}{*}{$\leq 50000$} \\
\hline & 2 & $2.7 \times 10^{6 b}$ & $7 \times 10^{c}$ & \\
\hline \multirow{2}{*}{ Mold \&yeast } & 1 & $9.0 \times 10^{5 c}$ & $1 \times 10^{d}$ & \multirow{2}{*}{$\leq 500$} \\
\hline & 2 & $6.6 \times 10^{5 d}$ & $20 \times 10^{a}$ & \\
\hline \multirow{2}{*}{ Staphylococcus aureus } & 1 & $\mathrm{Nil}^{\mathrm{h}}$ & $\mathrm{Nil}^{\mathrm{e}}$ & \multirow{2}{*}{ Nil } \\
\hline & 2 & $\mathrm{Nil}^{\mathrm{h}}$ & $\mathrm{Nil}^{\mathrm{e}}$ & \\
\hline \multirow{2}{*}{ Bacillus cereus } & 1 & $3.2 \times 10^{3 e}$ & $\mathrm{Nil}^{\mathrm{e}}$ & \multirow{2}{*}{$\leq 10000$} \\
\hline & 2 & $5.2 \times 10^{2 f}$ & $\mathrm{Nil}^{\mathrm{e}}$ & \\
\hline \multirow{2}{*}{ E. Coli } & 1 & $1.2 \times 10^{2 \mathrm{~g}}$ & $\mathrm{Nil}^{\mathrm{e}}$ & \multirow{2}{*}{$\leq 10$} \\
\hline & 2 & $2.7 \times 10^{2 g}$ & $\mathrm{Nil}^{\mathrm{e}}$ & \\
\hline
\end{tabular}

${ }^{*} \mathrm{cfu} / 1 \mathrm{gm}=$ colony forming unit $/ 1 \mathrm{gm}$.

*The limits are according (E.S: 1629:2017).

* Values followed by different letter in columns are significantly different at $p<0.05$. 
Rasha A. M. Eissa, et al.,

\section{HACCP plan}

\subsection{Product description and intended use}

A full description of the product should be drawn up, including relevant safety information such as: composition, physical/chemical structure, microbiological characteristics and nutritional value. Ingredients and materials used for potatoes chips manufacturing and the intended use of the product are described in Table (7). The intended use should be based on the expected uses of the product by the consumer. As considered against the following headings and recorded as HACCP study notes (SCV, 2006).

Table (7): Product description and intended use.

\begin{tabular}{|c|c|c|}
\hline Item & \multicolumn{2}{|c|}{ Product description } \\
\hline Product name & \multicolumn{2}{|c|}{ Fresh slice potato frying in vegetarian oil } \\
\hline Product description & \multicolumn{2}{|c|}{$\begin{array}{l}\text { Potato slices } 8 \text { flavors (chili- cheese-salt - salt \&vinegar - } \\
\text { spicy cheese - kebab- chicken - ketchup) }\end{array}$} \\
\hline Physical properties & \multicolumn{2}{|c|}{$\begin{array}{l}\text { Product should be free from rancidity, undesirable odor and } \\
\text { slices color } \geq 55 \mathrm{~L}\end{array}$} \\
\hline $\begin{array}{l}\text { Chemical } \\
\text { characteristics }\end{array}$ & \multicolumn{2}{|c|}{$\begin{array}{l}\text { Moisture (3\%), Oil (40\%), salt before seasoning (3\%), Ash (4\%) } \\
\text { and Free fatty acid (FFA) }(1.5 \%) \text { as oleic oil. }\end{array}$} \\
\hline $\begin{array}{l}\text { Microbiological } \\
\text { characteristics }\end{array}$ & \multicolumn{2}{|c|}{$\begin{array}{l}\text { Product should be free from microorganisms and pathogenic } \\
\text { microbes which causing poisoning and their toxin, bacteria } \\
\text { count } 50000 \mathrm{cfu} \text {, Bacillus count maximum } 10000 \mathrm{cfu} \text {. }\end{array}$} \\
\hline \multirow[b]{2}{*}{$\begin{array}{l}\text { Nutritional } \\
\text { l10gm }\end{array}$} & Parameters & Amount (gm) \\
\hline & $\begin{array}{l}\text { Fat } \\
\text { Protein } \\
\text { Carbohydrate } \\
\text { Saturated fat } \\
\text { Un Saturated fat } \\
\text { Cholesterol } \\
\text { Fiber } \\
\text { Vitamin A } \\
\text { Vitamin C } \\
\text { Sodium } \\
\text { Calcium } \\
\text { Iron } \\
\text { Calories } / 10 \mathrm{~g}\end{array}$ & $\begin{array}{c}3.94 \\
0.67 \\
4.27 \\
1.22 \\
2.72 \\
0.0 \\
1.12 \\
0.0 \\
0.003 \\
0.05 \\
0.003 \\
0.003 \\
65.27 \mathrm{kcal}\end{array}$ \\
\hline Raw\& packing material & \multicolumn{2}{|c|}{$\begin{array}{l}\text { Potato - palm oleic oil - flavor - film PPM } 40 \mu \text { - Carton single B } \\
\text { - printing rolls - adhesive rolls - a starch roll. }\end{array}$} \\
\hline $\begin{array}{l}\text { Stock keeping units } \\
\text { SKUs }\end{array}$ & \multicolumn{2}{|c|}{$13-17 \mathrm{mg}, 24-28 \mathrm{gm}, 62-72 \mathrm{gm}$} \\
\hline Storage conditions & \multicolumn{2}{|c|}{ Store in a cool and dry place away from sunlight. } \\
\hline Distribution method & \multicolumn{2}{|c|}{ Malls - supermarkets - restaurants - retails - big markets. } \\
\hline Shelf life & \multicolumn{2}{|c|}{6 months. } \\
\hline $\begin{array}{l}\text { Customer } \\
\text { requirements }\end{array}$ & \multicolumn{2}{|l|}{ Direct consumption. } \\
\hline $\begin{array}{l}\text { Intended Use/target } \\
\text { group }\end{array}$ & \multicolumn{2}{|c|}{ Ready for consumption for all ages. } \\
\hline
\end{tabular}

According to Egyptian standard E. S 1629/2017, PPM: Polypropylenemetalize. 


\subsection{On-site verification of flow diagram: and process step}

All processes steps activities are described in details to explain the purpose of each step in the process.

\subsection{Hazard analysis (List hazards, conduct hazard analysis, consider control measures)}

Collect information about hazards and evaluating hazard analysis and hazard assessment is being done for each step of potatoes chips manufacturing starting from receiving till finished product storage.

\subsection{Determining CCPs and it is critical limits:}

Decision tree to determining CCPs must be done for each identified significant hazard (CAC/RCP-4, 2003). To determine the critical limits for each CCP by using list of supporting documents and as well as OPRP are necessary. To differentiate between the control measure classifications either CCP or OPRP for each identified significant hazard using (ISO 22004, 2014) as shown in Table (8).

Easdani et al. (2012) included hazard description, critical limit, observation procedure, responsible person, monitoring procedure and corrective action in his HACCP control chart for production of potato chips plant in Bangladesh. Metal detector was only CCPs found in the processing of potato chips its represent physical hazard and three OPRP were found in the processing of potato chips. It is receiving potato "Physical hazard", frying potato "Chemical hazard" and frying potato "microbiological hazard ". Records of monitoring must be kept to ensure the effectiveness of the HACCP system.
All CCPs, OPRP points identified should be monitored and verified as shown in Table (9).

\section{Finished products control:}

After the implementation of the food safety program and ensuring its effectiveness. According to the HACCP plan, samples were taken from the finished product and the results obtained from Table (10) showed that microbiological tests carried out on the finished products were within the permissible limits and that the product is completely free of pathogens. Also the results of chemical tests and physical properties includes packaging quality evaluation (scrap breakage, greening, peel removal and defects) showed that the product is within the permitted limits and of high quality according to the Egyptian standards. Physicochemical properties including moisture content, oil, salt, color, and absolute density in three types of potato chips are listed in Table (10). There was no difference in moisture content among the three types of potato chips. It was observed that fried potato chips (FPC) contained the highest oil content. Finally, sensory parameters (color, taste, odor, texture and acceptability). Sensory acceptability scores differed depending on the salt concentrations used for the preparation of potato chip samples which affects the liking of food products. Results of the sensory tests of the product also showed that it is acceptable according to consumer taste and marketing requirements. All above mentioned elements are considered the release criteria of the product. Our results are in agreement with Dona and Davidson (2000); Krokida et al. (2000) and Pedreschi and Aguilera (2002). 
Rasha A. M. Eissa, et al.,

Table (8): Consider control measure and classification it into (CCP or OPRP).

\begin{tabular}{|c|c|c|c|c|c|c|c|c|c|c|}
\hline \multicolumn{3}{|c|}{ Step and Hazard } & $\begin{array}{l}\text { Control } \\
\text { measures }\end{array}$ & \multicolumn{7}{|c|}{$\begin{array}{l}\text { To Categorization of control measures in OPRPs and CCPs. Answer } \\
\text { questions. }\end{array}$} \\
\hline \multirow{5}{*}{\multicolumn{3}{|c|}{$\begin{array}{l}\text { Transferred hazards which } \\
\text { considered as significant } \\
\text { from the hazard } \\
\text { assessment }\end{array}$}} & \multirow{5}{*}{$\begin{array}{c}\text { Select and } \\
\text { describe a } \\
\text { control } \\
\text { measure or } \\
\text { combination- } \\
\text { of control } \\
\text { measures } \\
\text { capable of } \\
\text { preventing, } \\
\text { eliminating } \\
\text { or reducing } \\
\text { the hazard } \\
\text { to an } \\
\text { acceptable } \\
\text { level. }\end{array}$} & \multicolumn{7}{|c|}{$\begin{array}{l}\text { Q1: Based on the likelihood of occurrence and the severity of } \\
\text { adverse health effects, is this hazard significant? (see hazard } \\
\text { assessment table) YES: This is a significant hazard. Go to Q2. NO: } \\
\text { This is not a significant hazard. }\end{array}$} \\
\hline & & & & \multicolumn{7}{|c|}{$\begin{array}{l}\text { Q2: Will subsequent steps alone or in combination guarantee } \\
\text { the removal of this significant hazard, or its reduction to an } \\
\text { acceptable level? YES: Identify and name subsequent step. NO: } \\
\text { Go to Q3. }\end{array}$} \\
\hline & & & & \multirow[b]{4}{*}{ Q1 } & \multirow[b]{4}{*}{ Q2 } & \multicolumn{5}{|c|}{$\begin{array}{l}\text { Q3: Are control measures or practices in place at this step } \\
\text { and do they exclude, reduce or maintain this significant } \\
\text { hazard as necessary? } \\
\text { YES: Go to Q4. NO: Modify the process or product and go } \\
\text { to Q1. }\end{array}$} \\
\hline & & & & & & \multirow[b]{3}{*}{ Q3 } & \multicolumn{4}{|c|}{$\begin{array}{l}\text { Q4: Is it necessary to establish critical limits for the } \\
\text { control measure at this step? } \\
\text { YES: Go to Q5. NO: This hazard is managed by an } \\
\text { OPRP. }\end{array}$} \\
\hline & & & & & & & \multirow[b]{2}{*}{ Q4 } & \multicolumn{3}{|c|}{$\begin{array}{l}\text { Q5: Is it necessary to monitor the control } \\
\text { measure in such a way that action can be taken } \\
\text { immediately when there is a loss of control? } \\
\text { YES: This hazard is managed by control } \\
\text { measures at a CCP. NO: This hazard is } \\
\text { managed by an OPRP. }\end{array}$} \\
\hline S.N & Step & Hazard & $\begin{array}{l}\text { Description } \\
\text { of control } \\
\text { measures }\end{array}$ & & & & & Q5 & $\begin{array}{l}\text { CCP I } \\
\text { OPRP }\end{array}$ & Justification for decision \\
\hline 1 & Receiving & $\begin{array}{l}\text { physical } \\
\text { hazard } \\
\text { (foreign } \\
\text { bodies) }\end{array}$ & $\begin{array}{l}\text { Perforated } \\
\text { conveyer }\end{array}$ & Yes & No & Yes & No & No & OPRP1 & $\begin{array}{l}\text { Perforated conveyor is the step to } \\
\text { manage and control the physical } \\
\text { hazards by trapping of (Foreign } \\
\text { bodies } \leq 2 \mathrm{~cm} \text {, dusts, stones, and } \\
\text { sprout ...etc.) followed by } \\
\text { washing process step. }\end{array}$ \\
\hline 2 & Frying & $\begin{array}{c}\text { Microbiology } \\
\text { hazard } \\
\text { (temperature) }\end{array}$ & $\begin{array}{l}\text { monitoring } \\
\text { temperature }\end{array}$ & Yes & No & Yes & Yes & No & OPRP2 & $\begin{array}{l}\text { Frying at }\left(175-180^{\circ} \mathrm{C}\right) \text { kills } \\
\text { microorganisms present in } \\
\text { potatoes and this step ensure that } \\
\text { fried slices are within safe limits. }\end{array}$ \\
\hline 3 & Frying & $\begin{array}{l}\text { Chemical } \\
\text { Hazard } \\
\text { (FFA \%) }\end{array}$ & $\begin{array}{c}\text { matrix oil } \\
\text { management }\end{array}$ & Yes & No & Yes & Yes & No & OPRP3 & $\begin{array}{l}\text { Frying is the step to manage and } \\
\text { control the content of free fatty } \\
\text { acids in the acceptable limits and } \\
\text { this step is designed for this } \\
\text { purpose. }\end{array}$ \\
\hline 4 & Packaging & $\begin{array}{l}\text { Physical } \\
\text { hazard } \\
\text { (ferrous/non } \\
\text { ferrous } \\
\text { Isteel) }\end{array}$ & $\begin{array}{l}\text { In line } \\
\text { metal } \\
\text { detector }\end{array}$ & Yes & No & Yes & Yes & Yes & CCP1 & $\begin{array}{l}\text { Metal detector is specially } \\
\text { designed and it is the last step for } \\
\text { physical hazard elimination. }\end{array}$ \\
\hline
\end{tabular}




\begin{tabular}{|c|c|c|c|c|}
\hline 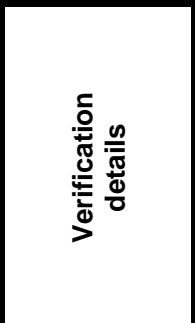 & 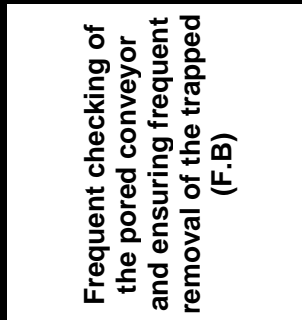 & 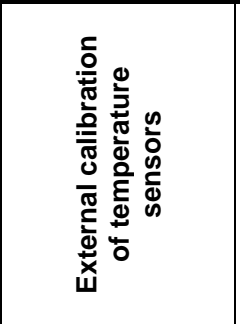 & 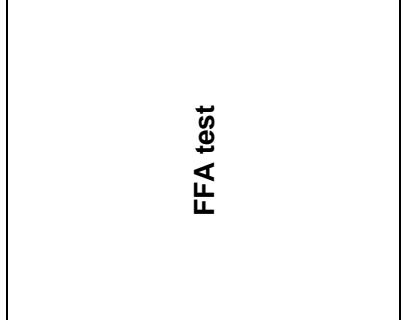 & 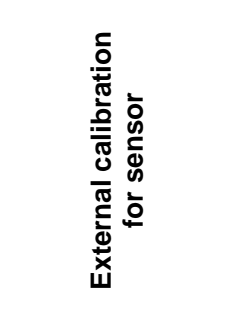 \\
\hline 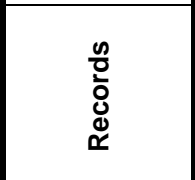 & 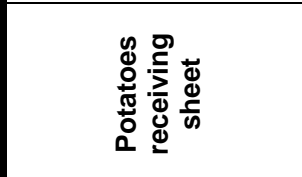 & 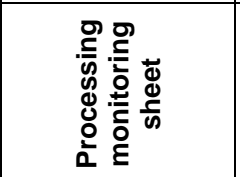 & 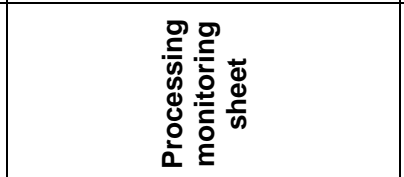 & 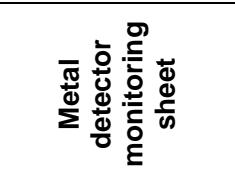 \\
\hline 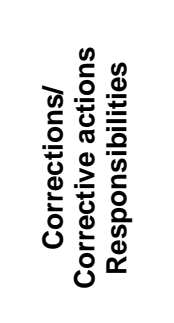 & 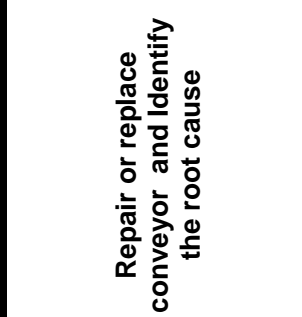 & 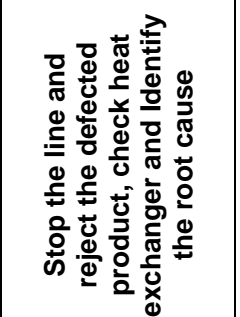 & 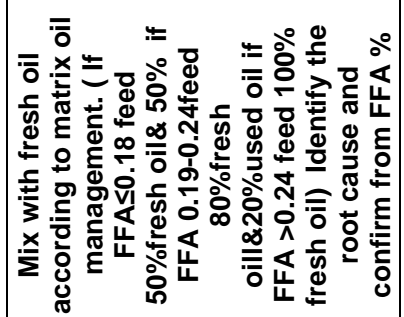 & 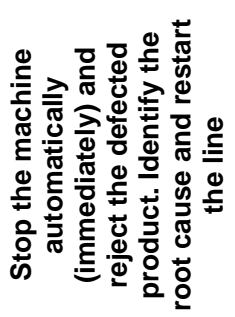 \\
\hline$\frac{\circ}{3}$ & 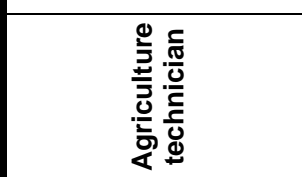 & 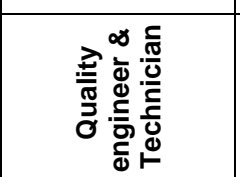 & 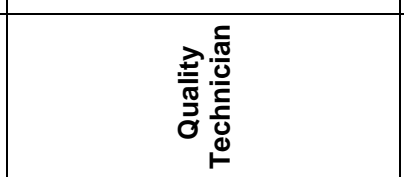 & 竞 \\
\hline $\begin{array}{l}\vec{む} \\
\frac{\bar{d}}{J} \\
\overline{0} \\
\frac{0}{4}\end{array}$ & 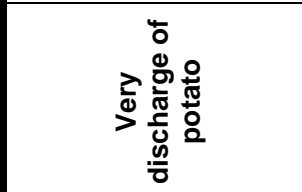 & 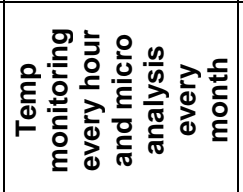 & 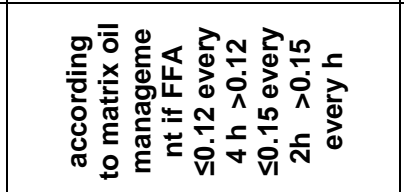 & 䇾言 \\
\hline $\begin{array}{l}3 \\
\text { Oo } \\
\end{array}$ & 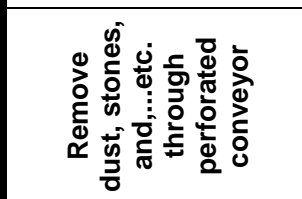 & 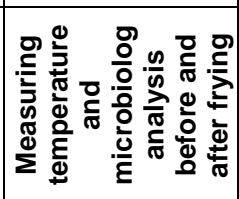 & 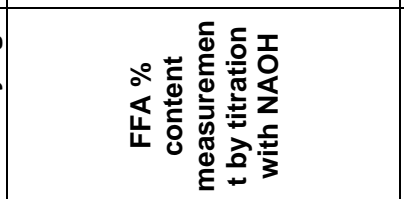 & 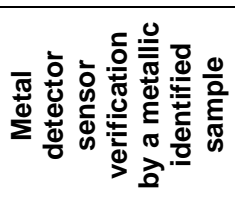 \\
\hline 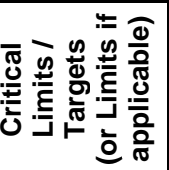 & 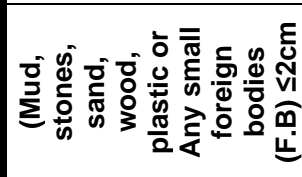 & 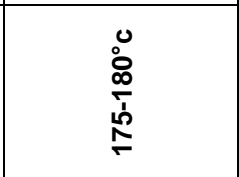 & 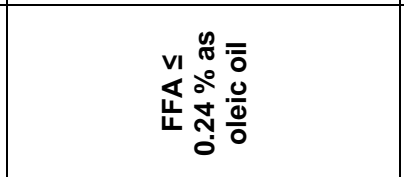 & 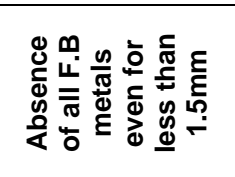 \\
\hline 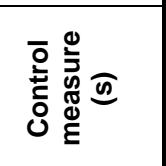 & 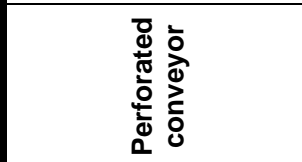 & 舟 & 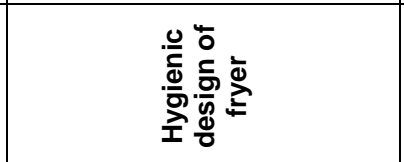 & 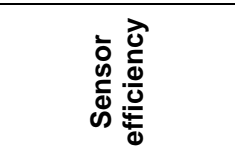 \\
\hline 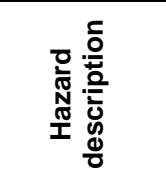 & 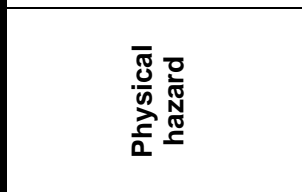 & 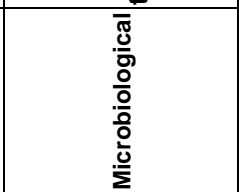 & 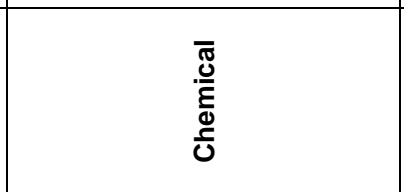 & 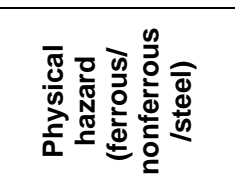 \\
\hline \multirow[t]{2}{*}{ 产 } & 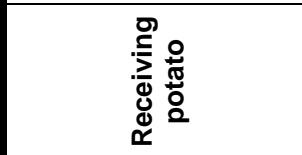 & 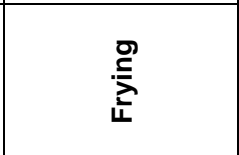 & 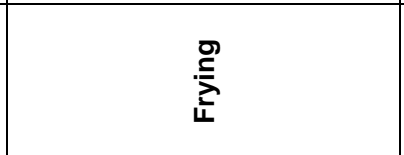 & 嵒 \\
\hline & $\begin{array}{l}\frac{1}{0} \\
\frac{\pi}{0} \\
0\end{array}$ & $\begin{array}{l}\text { N } \\
\frac{\tilde{\alpha}}{\alpha} \\
0\end{array}$ & $\begin{array}{l}m \\
\frac{0}{\alpha} \\
\frac{\pi}{0} \\
0\end{array}$ & d- \\
\hline
\end{tabular}


Rasha A. M. Eissa, et al.,

Table (10): Microbiological, chemical analysis, physical properties and sensory evaluation of finished products.

\begin{tabular}{|c|c|c|c|c|}
\hline \multirow{2}{*}{ Parameters } & \multirow{2}{*}{ Limits } & \multicolumn{3}{|c|}{ Products } \\
\hline & & Cheese & Kebab & Ketchup \\
\hline $\begin{array}{l}\text { Microbiological tests (cfu/gm) } \\
\text { Total plate count } \\
\text { mold\& yeast } \\
\text { Bacillus cereus } \\
\text { Salmonella* } \\
\text { Staphylococcus aureus } \\
\text { E. Coli } \\
\text { Coliform group }\end{array}$ & $\begin{array}{c}\leq 50000 \\
\leq 500 \\
\leq 1000 \\
\mathrm{Nil} \\
\mathrm{Nil} \\
\mathrm{Nil} \\
\leq 10\end{array}$ & $\begin{array}{c}2.5^{\times 10^{2 \mathrm{c}}} \\
1.1^{\times 10^{2 \mathrm{c}}} \\
\mathrm{Nil} \\
\mathrm{Nil} \\
\mathrm{Nil} \\
\mathrm{Nil} \\
\mathrm{Nil}\end{array}$ & $\begin{array}{c}3.7 \times 10^{2 b} \\
1.4^{\times} 10^{2 b} \\
\text { Nil } \\
\text { Nil } \\
\text { Nil } \\
\text { Nil } \\
\text { Nil }\end{array}$ & $\begin{array}{c}4.5 \times 10^{2 a} \\
1.8^{\times 10^{2 a}} \\
\mathrm{Nil} \\
\mathrm{Nil} \\
\mathrm{Nil} \\
\mathrm{Nil} \\
\mathrm{Nil}\end{array}$ \\
\hline $\begin{array}{l}\text { Chemical analysis } \\
\text { Free Fatty Acids content (\%) } \\
\text { Moisture content }(\%) \\
\text { Oil content }(\%) \\
\text { Peroxide value (mEq/Kg) } \\
\text { Salt content after seasoning } \\
(\%) \\
\text { Ash }\end{array}$ & $\begin{array}{c}\leq 1.5 \\
\leq 3 \% \\
\leq 40 \% \\
\leq 10 \\
(4.5-5.5) \\
\leq 4 \%\end{array}$ & $\begin{array}{c}0.22 \\
1.35 \\
33.43 \\
5.3 \\
4.8 \\
3.55\end{array}$ & $\begin{array}{c}0.22 \\
1.35 \\
33.43 \\
5.3 \\
4.9 \\
3.59\end{array}$ & $\begin{array}{c}0.22 \\
1.35 \\
33.43 \\
5.3 \\
5.1 \\
3.45\end{array}$ \\
\hline $\begin{array}{l}\text { Physical properties } \\
\text { Breakage } \\
\text { Complete - In bag } \\
\text { Greening } \\
\text { Peel removal } \\
\text { Defects }\end{array}$ & $\begin{array}{c}\leq 15 \% \\
\geq 60 \% \\
\leq 3 \% \\
90 \%-95 \% \\
\leq 12 \%\end{array}$ & $\begin{array}{c}6 \% \\
85 \% \\
1.9 \% \\
90 \% \\
7.8 \%\end{array}$ & $\begin{array}{c}7 \% \\
80 \% \\
1.8 \% \\
92 \% \\
7.9 \%\end{array}$ & $\begin{array}{c}9 \% \\
75 \% \\
1.9 \% \\
94 \% \\
7.8 \%\end{array}$ \\
\hline $\begin{array}{l}\text { Sensory evaluation } \\
\text { Color } \\
\text { Taste } \\
\text { Odor } \\
\text { Texture(crispness) } \\
\text { Overall acceptability }\end{array}$ & $\begin{array}{l}\geq 5 \\
\geq 5 \\
\geq 5 \\
\geq 5 \\
\geq 5\end{array}$ & $\begin{array}{c}8 \\
7 \\
8 \\
7 \\
7.50\end{array}$ & $\begin{array}{c}7 \\
8 \\
7 \\
7 \\
7.25\end{array}$ & $\begin{array}{c}6 \\
6 \\
6 \\
6 \\
6.00\end{array}$ \\
\hline
\end{tabular}

* cfu $/ 1 \mathrm{gm}$ = colony forming unit $/ \mathrm{gmm}$ * Salmonella only cfu $/ 25 \mathrm{gm}$.

*The limits are according Egyptian standard for fried potato (E.S: 1629:2017).

* Values followed by different letter in rows are significantly different at $p<0.05$.

\section{REFERENCES}

A.O.A.C. (2005). Association of Official Analytical Chemists Official Methods of Analysis of the Association of Official Analytical Chemists. $18^{\text {th }}$ Ed. Washington, DC, USA.

A.O.C.S (2005). American Oil Chemists' Society and Firestone, D. Official methods and recommended practices of the American Oil Chemists' Society. AOCS press.
Abd-Elhak, M. Z. (2005). Potato production and storage in Egypt. Egyptian Ministry of Agriculture: Issue no. 9 of The Horticulture Research Institute, 8.

CAC/RCP-4 (2003). Recommended international Code of practice general principles of food hygiene. in Codex Alimentarius commission Food Hygiene Basic Texts, $4^{\text {th }}$ Edition. Food and Agriculture Organizations of the 
United Nations, World Health Organization, Rome.

Codex (2009). Joint FAO/WHO Food Standards Programme, Codex Alimentarius Commission, Committee on Food Hygiene. Hazard analysis and critical control point (HACCP) system and guidelines for its application. Food Hygiene Basic Texts, fourth Edition. Joint FAO/WHO Food Standards Programme, Food and Agriculture Organizations of the United Nations, World Health Organization, Rome.

Dogan, H. and J. L. Kokini (2007). Psychophysical markers for crispness and influence of phase behavior and structure. J. Texture Stud. 38, 324-354.

Dona, H. Craig and Davidson, P. Michael (2000). Microbiology of potatoes and potato products: A review. J. of Food Protection, 63 (5): 668-683.

E.S: 1629 (2017). Egyptian organization for standardization and quality for Fried potato (28/8/2017).

Easdani, M., Khaliduzzaman and M. H. R. Bhuiyan (2012). The Design of HACCP Plan for Potato Chips Plant in Bangladesh. J. Environ. Sci. \& Natural Resources, 5(2): 329 - 338.

El-Sheikh, D. M. (1999). Production and evaluation of some low caloric jams. Ph. D. Thesis, Food Technology Dept., Fac. of Agric., Cairo Univ.

ES: 190-1 / (2007). Drinking water and ice standard test method part $\mathbf{- 1}$.

Forsythe, S. J. and P. R. Hayes (1998). Food Hygiene, Microbiology and HACCP and product quality $.3^{\text {rd }} \mathrm{ed}$. Aspen Publishers, Inc. Gaithersburg, Maryland.

ISO 22000 (2018). International standard organization ISO 22000. Food safety management systems-Requirements for any organization in the food chain second edition.

ISO $22004 \quad$ (2014). International Standardization Organization ISO
22004. Food safety management systems - Guidance on the application of ISO 22000 -First edition.

ISO9308-1/ (2000). International Standardization Organization.ISO9308. Water quality detection \&enumeration of E.coli\& coliform bacteria part-1 membrane filtration.

Khatab, Heba, A. (2014). Controlling of microbial hazard during the processing of mango pulp and juice through food safety management system (ISO 22000). MSc. Thesis, Food science and technology Depart., Fac. of Agric. Tanta Univ.

Krokida, M. K., V. Oreopoulou and Z. B. Maroulis (2000). Water loss and oil uptake as a function of frying time. Journal of Food Engineering, 44: 3946.

Majcher, M. A. and H. H. Jelen (2005). Identification of potent odorants formed during the preparation of extruded potato snacks. Journal of Agriculture and Food Chemistry, 53: 6432-6437.

Noble, R., J.G. Elphinstone, C.E. Sansford, G. E. Budge and C. M. Henry (2009). Management of plant health risks associated with processing of plant-based wastes: A review Bioresource Technology 100, 34313446.

Pedreschi, F. and J. Aguilera (2002). Some changes in potato chips during frying observed by confocal laser scanning microscopy (CLSM). Food Science and Technology International, 8(4), 197-201.

SCV (2006). Requirements for a HACCP based Food Safety, Option A: Management System Certification. National Board of Experts-HACCP. The Netherlands.

Zhang, L. and D. G. Peterson (2018). Review: Identification of a novel umami compound in potatoes and potato chips. Food Chemistry 240: 1219-1226. 
السيطرة على المخاطر المحتملة في تصنيع رقائق البطاطس من خلال نظام إدارة سلامة

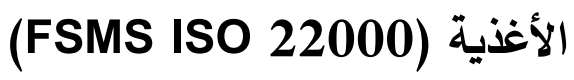

رشا عبد الحليم محمد عيسى(')، موسى عبده سالم(') ، سمير يوسف السناط(')

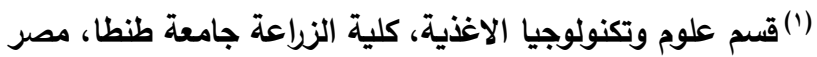

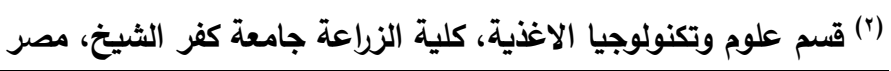
الملخص العربي تهاف هذه الاراسة إلى تصميم خطة تحليل المخاطر ونقاط التحكم الحرجة (HACCP) لإنتاج رقائق البطاطس من خلال نظام إدارة سلامة الأغذية FSMS ISO22000 بناءً على الظروف الفعلية في المصنع. تم تطوير نموذج محداط لتعزيز سلامة وجودة منتج رقائق البطاطس في هذا المصنع. تم تصميم برامج المتطلبات الاشتراطية الأولية (PRP)

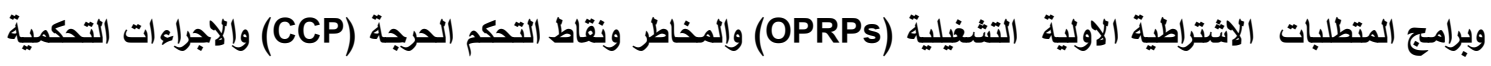

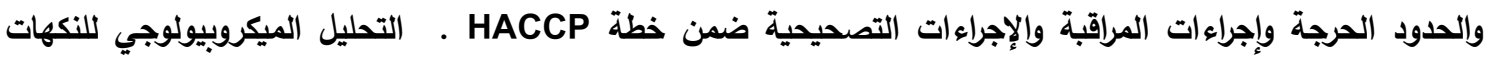

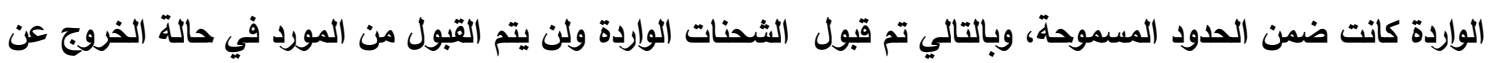

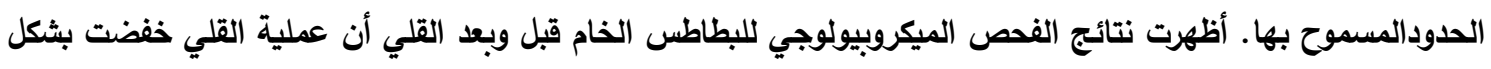
كبير جميع الكائنات الحية الاقيقة في البطاطس الخام إلى المستوى المقبول على خطي المعالجة. تم وضع بلى برنامج نظافة وتطهير خطوط الاتتاج وبرنامج النظافة الثخصية للعاملين والتأكد من فاعليتهم. تم اجراء الاختبارات الكيميائية، الميكروبيولوجية، الفيزيائية والحسية للتاكد من سلامة وجودة النطائه المنتج النهائى. 